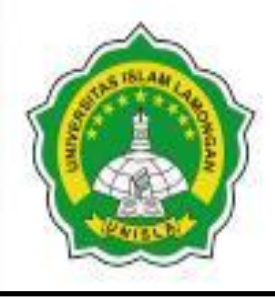

\title{
Neuro-Fuzzy for Traffic Volume Forecasting of National Road III Jember- Banyuwangi KM 252
}

\author{
Muhammad Shofwan Donny Cahyono ${ }^{1 *}$, Agustinus Angkoso ${ }^{2}$ \\ ${ }^{1 * 2,3}$ Faculty of Engineering. Civil Engineering \\ Email : ${ }^{1 *}$ donnycahyono88@gmail.com. ${ }^{2 *}$ agustinusangkoso@gmail.com
}

\section{A R T I C L E IN F O}

\section{Article History:}

Article entry : 20-08-2021

Article revised : 23-09-2021

Article received : 19-10-2021

\section{Keywords :}

National Road III Jember Banyuwangi KM 252; Forecasting Methods, NeuroFuzzy, Traffic Volume

\section{IEEE Style in citing this article: [Heading citation] \\ One, N. P., \& Second, N. P. (Year). Article Title. \\ Civilla : Universitas Islam Lamongan, $v(n)$, Start page - End page. [heading citation contents]}

\begin{abstract}
A B S T R A C T
Traffic congestion is one of the prevalent phenomena in Indonesia, especially in big cities. There are a variety of factors causing congestion in the city, including the expansion of existing infrastructure, the large number of residents in the area, and the disparity between the growth of motor vehicles and highways. By careful transport planning, this can be fixed. The estimation of traffic volume is one strategy to see how much road growth is to offset vehicle volume growth to prevent congestion. This study tries to estimate the traffic volume of National Road III JemberBanyuwangi KM 252 motorized 2-wheeled vehicles passing by. The data used were obtained from 24 hours observation for 7 days. Using the Neuro-Fuzzy method which applies 1 day out of 7 days as testing data, and obtaining the average error is $13.2747 \%$. This average error shows that the error rate that occurs is $5 \%$ of all errors. Neuro-Fuzzy can forecast the traffic volume of 2-wheeled motorized vehicles reasonably well.
\end{abstract}

Copyright (C) 2021 Muhammad Shofwan Donny Cahyono, dkk. This work is licensed under a Creative Commons Attribution-ShareAlike 4.0 International License. Allows readers to read, download, copy, distribute, print, search, or link to the full texts of its articles and allow readers to use them for any other lawful purpose. 


\section{Introduction}

As a basic network infrastructure for the existence of a city or region, transportation planning is important for the sustainability and growth of a city or region, especially in large cities [1][2]. Planning transportation still needs traffic volume forecasting. The amount of traffic is the number of vehicles on a road crossing a certain point or line. The information required for the planning, design, management and road operations phases is traffic volume enumeration data.

In order to obtain daily data variations and variations in peak hours on regular days and holidays, the data collection of the traffic volume under analysis was conducted using the actual survey approach with a minimum length of $7 \times 24$ hours on national roads[3]. This traffic forecast would explain how the vehicles on a certain road are congested [4][5]. From this data, it is possible to make a traffic density forecast that will occur in the coming years, so that local officials in the region can determine how many roads should be constructed to prevent potential congestion.

There are several variables that cause congestion in an area much of the time. The first is the presence in infrastructure growth. In a city, there are different infrastructures, such as tourist destinations, shopping centers, new settlements, and so on. Several new infrastructures are constructed in a city, the desire of the community to go to that place would be even greater. The more people who leave, the greater the risk of congestion occurring in the city. This is one aspect that creates congestion in traffic.

The second factor that causes congestion is the increasing population growth. According to the Central Statistics Agency, population growth in the last 10 years, namely 2010-2020, population growth rate reached $1.25 \%$ per year. Meanwhile, the total population of Indonesia in 2020 is 270.2 million [6]. The population growth prediction also points to the level of congestion in the area. It is because the more the population, the more mobility that occurs in an area. Definitely will cause congestion.

The third factor that affects congestion in an area is the imbalance between the growth of motor vehicles and the growth of roads. This imbalance causes traffic congestion on a road. According to data, the number of motorized vehicles increases with a growth rate of up to $7.2 \%$ per year. In fact, according to the forecast in the Decree of the Director-General of Highways, that the traffic growth factor is based on historical growth data and the correlation between other growth factors can be described as follows: 
1. Arterial and urban roads with the growth of 5\% for 2011-2020 and 4\% for 2021-2030.

2. Rural roads with 3.5\% growth for 2011-2020 and 2.5\% for 2021-2030.

These data show that there is an imbalance in the number's growth of motorized vehicles and the growth of roads [7][8].

These factors reflected that the study of traffic volume prediction is very important. This forecasting process will be adjusted to the form of the mathematical pattern of vehicle growth under review. In this study, this pattern will be recognized using the Neuro-Fuzzy method. One advantage of the Neuro-Fuzzy method is that it can recognize a pattern using training techniques based on past data. Neuro-Fuzzy will predict the volume of traffic on the national road III Jember-Banyuwangi KM 252. It is hoped that this research can be a basic study to predict traffic volume on a road so that transportation planning in an area can be even better.

\section{Literature Review}

Neuro-Fuzzy is a method that combines fuzzy logic and neural networks. Fuzzy logic is a logic whose values are blurred where the magnitude is between zero (0) and one (1) or true and false. Lotfi A. Zadeh created fuzzy logic in 1965[9]. This fuzzy logic is widely used in the fields of decision theory, control, and others. The advantage of fuzzy is that we can use fuzzy logic in most cases of problems that occur in the actual world. This is because most of the problems in the actual world are non-linear and not binary, so that they can express linguistic concepts which are often difficult to formulate.

Meanwhile, the neural network is a network model whose work is inspired by the workings of neurons in human nerves [10]. Neural network comprises nodes that are connected to each other through a link [11][12][13]. The links that connect these neurons in a neural network are often called weights. The advantage of a neural network is that it is used to gain knowledge from imprecise data. In addition, this network can recognize patterns and detect complex trends [14][15].

A new technique that is a combination of fuzzy logic and neural networks, namely NeuroFuzzy, is then used to establish the advantages of fuzzy logic and neural networks [16][17]. The combination of both is inspired by the way of thinking that humans can interpret uncertain data. Such uncertainty makes human choices about data incompetent or rigid. The machine would also change order to provide a smoother learning experience. Figure 1 demonstrates the ANFIS architecture. 


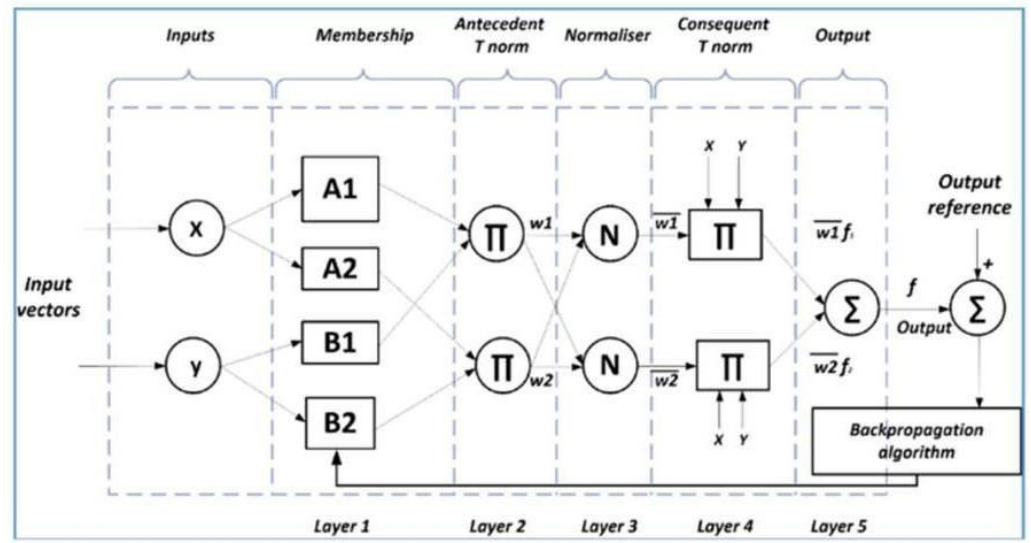

Source: Research results (2021)

Figure 1. ANFIS architecture

The workings of each layer shown in Figure 1 can be described as follows:

\section{Layer 1}

The function of this 1 st layer is to carry out the fuzzyfication process. The output at node $\mathrm{i}$ at layer 1 is denoted as $\mathrm{O}_{1, \mathrm{i}}$. Each node in layer 1 is adaptive to the outputs shown in (1) and (2). Where $\mathrm{x}$ and $\mathrm{y}$ are the input values for nodes and Ai or Bi is a fuzzy set. So each node in layer 1 is to produce a degree of membership[18].

$O_{1, \mathrm{i}}=\mu_{\text {Æi }}\left(x_{1}\right), i=1,2$

$O_{1, \mathrm{i}}=\mu_{\mathrm{Bi}}\left(x_{2}\right), i=3,4$

\section{Layer 2}

The 2nd layer is denoted as $\pi$. Each node in this layer is used to calculate the firing strength of each rule in the previous layer as the output of all incoming inputs. The output of this layer is shown in (3)[19].

$O_{2, \mathrm{i}}=w_{\mathrm{i}}=\mu_{Æ i}\left(x_{1}\right) \mu_{\mathrm{Bi}}\left(x_{2}\right), i=1,2$

So,

$w_{1}=\mu_{Æ 1}\left(x_{1}\right) A N D \mu_{\mathrm{B} 1}\left(x_{2}\right)$

$w_{2}=\mu_{Æ 2}\left(x_{1}\right) A N D \mu_{\mathrm{B} 2}\left(x_{2}\right)$ 


\section{Layer 3}

The 3rd layer is denoted by N. Each node in this layer is non-adaptive, which functions to calculate the ratio of firing strength in rule I to the total firepower of all rules. The output of layer 3 is shown in (6)[20].

$O_{3, \mathrm{i}}=\bar{w}_{\mathrm{i}}=\frac{\mathrm{wi}}{\mathrm{w}_{1}+\mathrm{w}_{2}}, i=1,2$

4. Layer 4

In this 4th layer, each node is an adaptive node as a function of equation (7)[21].

$0_{4, \mathrm{i}}=\bar{W}_{\mathrm{i}} f_{\mathrm{i}}=\bar{w}_{\mathrm{i}}\left(p_{\mathrm{i}} x_{1}+q_{\mathrm{i}} x_{2}+r_{\mathrm{i}}\right)$

Where is the output from the 3rd layer and $\left\{p_{\mathrm{i}} x_{1}+q_{\mathrm{i}} x_{2}+r_{\mathrm{i}}\right\}$ is the parameter set in the fuzzy inference model which in this Neuro-Fuzzy uses first order Takagi Sugeno fuzzy inference.

5. Layer 5

Layer 5 consists of 1 single knot which is denoted by $\Sigma$. The function of layer 5 is to combine all the outputs from layer 4 whose values are based on the equation (8).

$0_{5, \mathrm{i}}=\sum_{\mathrm{i}} \bar{w}_{\mathrm{i} \mathrm{i}}=\frac{\sum_{\mathrm{i}} \mathrm{w}_{\mathrm{i}} \mathrm{f}_{\mathrm{i}}}{\sum_{\mathrm{i}} \mathrm{w}_{\mathrm{i}}}$

\section{Research Method}

This study using the data volume of traffic that occurs on National Road III Jember Banyuwangi KM 252. The location of the road can be seen in Figure 2 below.

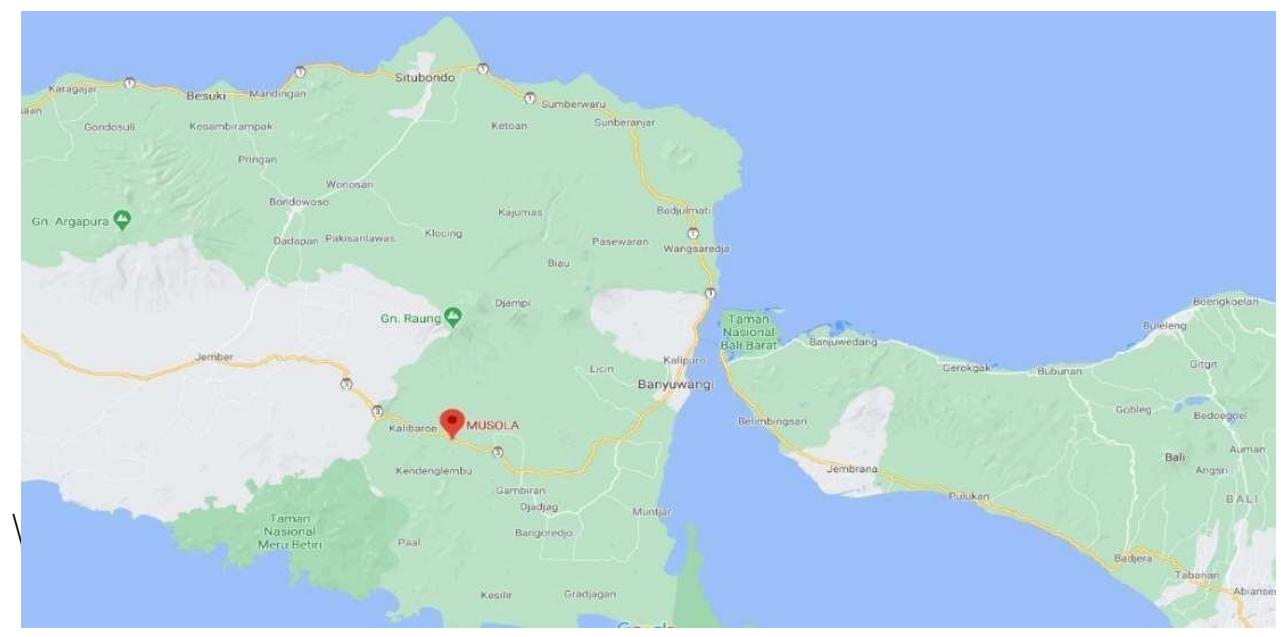

Source: Research results (2021)

Figure 2. Location of National Road III Jember Banyuwangi KM 252 
This traffic volume data collection method uses the direct survey method. This survey will count the number of vehicles passing National Road III Jember-Banyuwangi KM 252. The vehicles calculated are divided into 3 types, namely light vehicles as motorized vehicles with 4 wheels, heavy vehicles as motorized vehicles with over 4 wheels such as buses, trucks, and others, while a motorcycle is a motorized vehicle with 2 wheels such as a motorbike. The number of vehicles will be counted through observation for 7 days, starting from 11 May 2018 to 17 May 2018.

From this time of week, the number of vehicles is recorded per 1 hour for 24 hours. This 1 hour recording is carried out so that we can see the peak traffic volume that occurs on the road. In addition, this recording was carried out twice on the same road with different traffic directions. This is because in 1 road there are 2 roads that have different directions. It is very important to note these matters as material for the load analysis of the road. In this study, the types of vehicles to be analyzed are limited to motorbikes only. The results of the road traffic survey shown in Table 1 below.

Table 1. Volumes of Motorcycles on National Road III Jember Bayuwangi KM 252

\begin{tabular}{ccccccccc}
\hline \multirow{2}{*}{ No } & Time & & \multicolumn{7}{c}{ Mei 2018} \\
& & 11 & 12 & 13 & 14 & 15 & 16 & 17 \\
\hline 1 & $06.00-07.00$ & 703 & 658 & 367 & 460 & 663 & 485 & 531 \\
2 & $07.00-08.00$ & 537 & 458 & 405 & 427 & 535 & 343 & 377 \\
3 & $08.00-09.00$ & 454 & 387 & 405 & 394 & 420 & 488 & 419 \\
4 & $09.00-10.00$ & 368 & 367 & 379 & 360 & 412 & 506 & 545 \\
5 & $10.00-11.00$ & 427 & 358 & 342 & 358 & 443 & 542 & 453 \\
6 & $11.00-12.00$ & 391 & 395 & 382 & 425 & 453 & 436 & 450 \\
7 & $12.00-13.00$ & 418 & 360 & 340 & 379 & 389 & 405 & 411 \\
8 & $13.00-14.00$ & 338 & 335 & 344 & 342 & 340 & 388 & 321 \\
9 & $14.00-15.00$ & 362 & 340 & 324 & 370 & 326 & 345 & 379 \\
10 & $15.00-16.00$ & 460 & 463 & 365 & 463 & 512 & 393 & 409 \\
11 & $16.00-17.00$ & 448 & 403 & 400 & 359 & 435 & 474 & 383 \\
12 & $17.00-18.00$ & 369 & 394 & 357 & 383 & 389 & 272 & 430 \\
13 & $18.00-19.00$ & 530 & 575 & 490 & 378 & 598 & 374 & 418 \\
14 & $19.00-20.00$ & 457 & 502 & 488 & 350 & 542 & 330 & 388
\end{tabular}


Civilla : Jurnal Teknik Sipil Universitas Islam Lamongan

Volume 06 Number 2 Year 2021

\begin{tabular}{ccccccccc}
15 & $20.00-21.00$ & 301 & 307 & 325 & 131 & 346 & 158 & 241 \\
16 & $21.00-22.00$ & 148 & 171 & 171 & 125 & 182 & 133 & 148 \\
17 & $22.00-23.00$ & 138 & 146 & 154 & 81 & 163 & 104 & 112 \\
18 & $23.00-24.00$ & 55 & 69 & 58 & 94 & 73 & 117 & 97 \\
19 & $24.00-01.00$ & 31 & 46 & 45 & 29 & 47 & 34 & 50 \\
20 & $01.00-02.00$ & 38 & 24 & 28 & 30 & 29 & 22 & 31 \\
21 & $02.00-03.00$ & 63 & 24 & 48 & 22 & 26 & 15 & 29 \\
22 & $03.00-04.00$ & 121 & 38 & 37 & 23 & 45 & 19 & 37 \\
23 & $04.00-05.00$ & 185 & 119 & 55 & 38 & 127 & 45 & 96 \\
24 & $05.00-06.00$ & 185 & 281 & 96 & 74 & 379 & 83 & 133 \\
\hline
\end{tabular}

Source: Research results (2021)

\section{Results and Discussions}

\subsection{Neuro-Fuzzy Training}

In the Neuro-Fuzzy method, there are 2 stages, namely, the training stage and the testing phase. The training stages are carried out using past data. In this study, there was traffic volume data for 7 days, from 11 May 2018 to 17 May 2018. This data will be divided into 2, specifically data for training and data for testing. This training data will use traffic volume data from 11 May 2018 to 16 May 2018.

At this stage, the first thing to do is determine the Neuro-Fuzzy structure to use. This structure is influenced by 3 things, including:

1. Input membership function

2. Type of output membership function

3. Total membership function input

The Neuro-Fuzzy structure made in this study has an input as a clock and an output in the numbers form of motorbikes passing National Road III Jember Banyuwangi KM 252. In this Neuro-Fuzzy structure, a membership function is determined as a Gauss function with 10 membership function inputs. In addition, this structure uses a type of linear membership function from the output side of this network.

These data will be entered in MATLAB 2014a to form the Neuro-Fuzzy structure. After entering the data, the Neuro-Fuzzy structure in MATLAB 2014a will look like in Figure 3 below. 


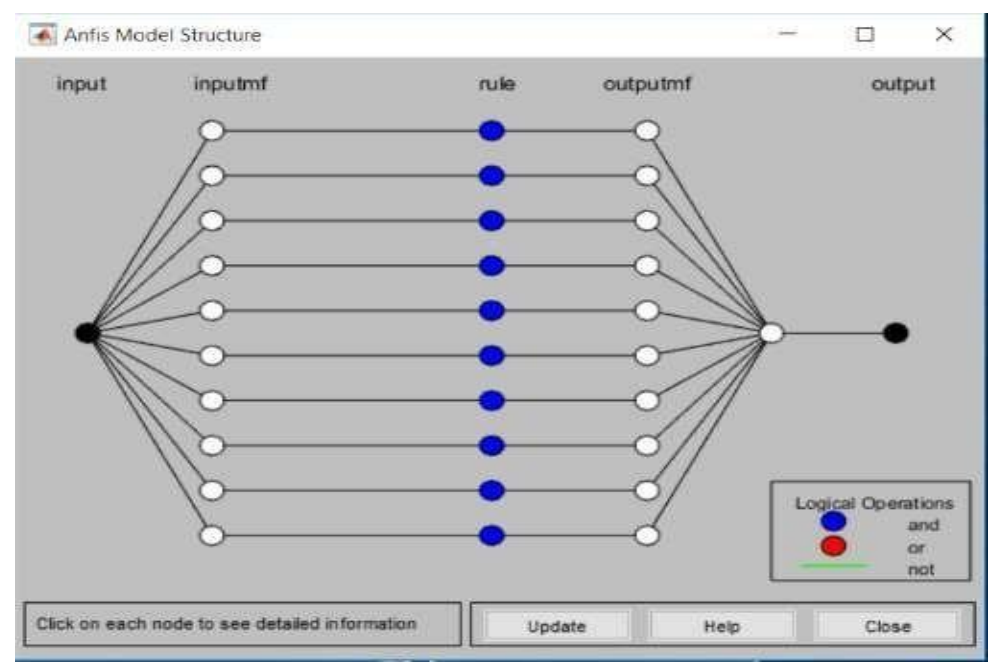

Source: Research results (2021)

Figure 3. Neuro-Fuzzy Structure

After that, the process was continued with a training process at MATLAB 2014a. This training process is repeated to form the Neuro-Fuzzy network. This repetition process is carried out as much as 1000 times or 1000 epoch. Figure 4 illustrates that this training process resulted in a small error rate of 0.18413

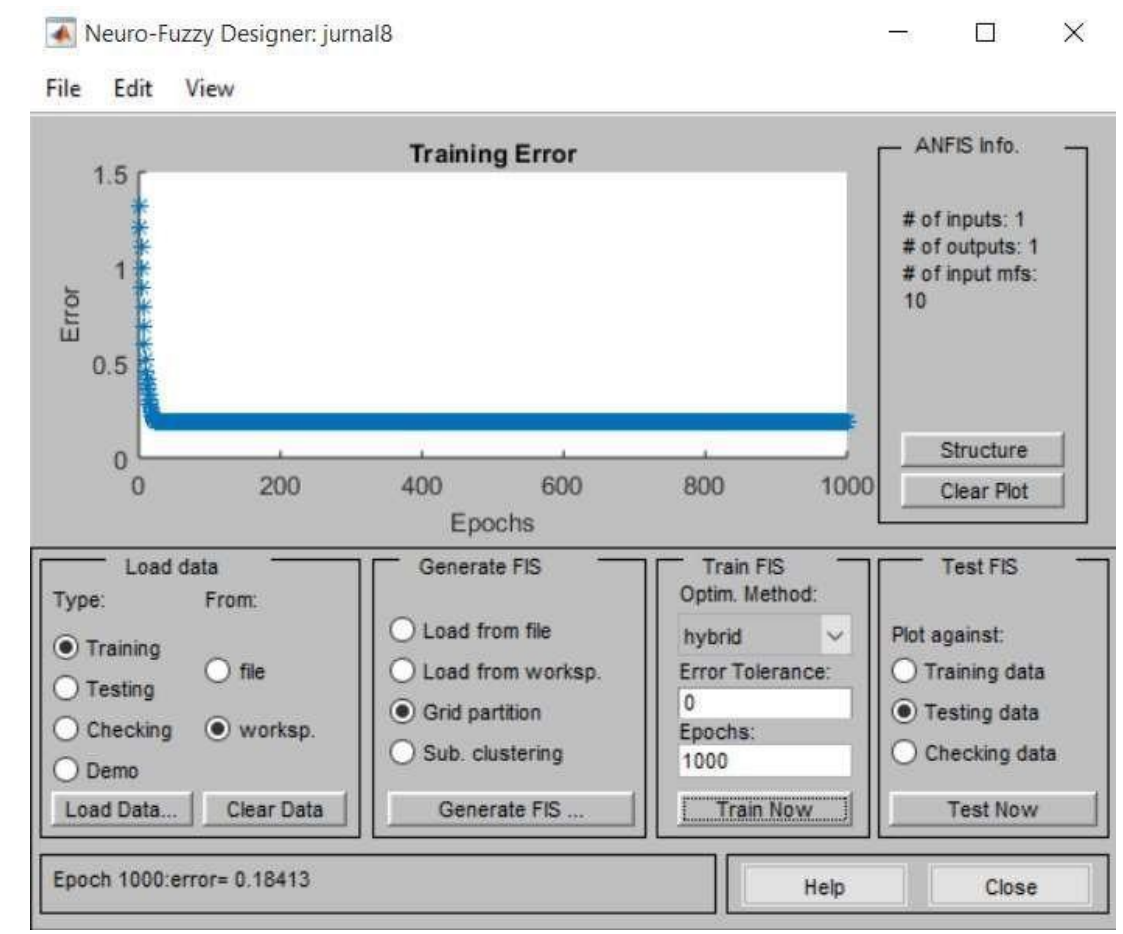

Source: Research results (2021)

Figure 4. Neuro-Fuzzy Training Process 


\subsection{Neuro-Fuzzy Testing}

After the training process, the next stage is testing the Neuro-Fuzzy structure. This NeuroFuzzy test is carried out by inputting the structure with motorbike traffic volume data on May 17, 2018. This input will produce a structure output (output). In calculating the forecast error rate using this structure, it is necessary to make a comparison between the output value of the structure that has been made (youtput) with the original value of the data on May 17, 2018 (yreal). The error rate for this Neuro-Fuzzy structure is calculated using the equation below.

$$
\% \text { Error }=\left|\frac{y_{\text {reas }}-y_{\text {output }}}{y_{\text {reas }}}\right| x 100 \%
$$

We can see the results of testing the Neuro-Fuzzy structure at this stage in Table 2 below.

Table 2. Neuro-Fuzzy Testing

\begin{tabular}{|c|c|c|c|c|}
\hline No & Time & Youtput & yreal & \%error \\
\hline 1 & $06.00-07.00$ & 556 & 531 & 4.708098 \\
\hline 2 & $07.00-08.00$ & 451 & 377 & 19.62865 \\
\hline 3 & 08.00-09.00 & 425 & 419 & 1.431981 \\
\hline 4 & $09.00-10.00$ & 399 & 545 & 26.78899 \\
\hline 5 & $10.00-11.00$ & 412 & 453 & 9.050773 \\
\hline 6 & $11.00-12.00$ & 414.1 & 450 & 7.977778 \\
\hline 7 & $12.00-13.00$ & 381.9 & 411 & 7.080292 \\
\hline 8 & $13.00-14.00$ & 348.1 & 321 & 8.442368 \\
\hline 9 & $14.00-15.00$ & 344.9 & 379 & 8.997361 \\
\hline 10 & $15.00-16.00$ & 443.1 & 409 & 8.337408 \\
\hline 11 & $16.00-17.00$ & 419.8 & 383 & 9.608355 \\
\hline 12 & $17.00-18.00$ & 361.1 & 430 & 16.02326 \\
\hline 13 & $18.00-19.00$ & 491 & 418 & 17.46411 \\
\hline 14 & $19.00-20.00$ & 444.9 & 388 & 14.66495 \\
\hline 15 & $20.00-21.00$ & 261.2 & 241 & 8.381743 \\
\hline 16 & $21.00-22.00$ & 154.7 & 148 & 4.527027 \\
\hline 17 & $22.00-23.00$ & 131.3 & 112 & 17.23214 \\
\hline
\end{tabular}




\begin{tabular}{ccccc}
06 & & & ISSN (Print) \\
\hline 18 & $23.00-24.00$ & 77.68 & 97 & 19.91753 \\
19 & $24.00-01.00$ & 39.34 & 50 & 21.32 \\
20 & $01.00-02.00$ & 28.69 & 31 & 7.451613 \\
21 & $02.00-03.00$ & 33.28 & 29 & 14.75862 \\
22 & $03.00-04.00$ & 46.77 & 37 & 26.40541 \\
23 & $04.00-05.00$ & 95.16 & 96 & 0.875 \\
24 & $05.00-06.00$ & 182.9 & 133 & 37.5188 \\
\hline
\end{tabular}

Source: Research results (2021)

From this test, it can be seen that the average error generated by Neuro-Fuzzy is $13.2747 \%$. This section contains (concise form) data analysis and interpretation of results. Interpretation of results using theories from articles as used. The descriptions is given include theoretical, implicative, and managerial, or practical.

\section{Conclusion and Suggestion}

This study creates a Neuro-Fuzzy network that is used to forecast the volume of traffic that occurs on National Road III Jember-Banyuwangi KM 252. The data in this study are primary data obtained through a survey process. This data contains the volume of traffic for 7 days, of which 6 days are used for the training process while the 1 day data is used for the testing process. The test results show that the Neuro-Fuzzy network has an average error generated by NeuroFuzzy is $13.2747 \%$ as can be seen in Table 2. Based on the value above, an error rate of $5 \%$ is obtained of all errors that occurred. In summary, Neuro-Fuzzy can forecast the volume of road traffic on National Road III Jember-Banyuwangi KM 252 satisfactorily.

\section{Acknowledgements}

First, the authors are thankful for Allah's blessings for the completion of the study on "Neuro-Fuzzy for Traffic Volume Forecasting of National Road III Jember-Banyuwangi KM 252" The two authors would also like to thank the University of Widya Kartika for helping to carry out this study in the infrastructure.

\section{References}


[1] D. P. Sari, F. Bu'ulolo, and S. Ariswoyo, "Optimasi Masalah Transportasi Dengan Menggunakan Metode Potensial Pada Sistem Distribusi PT. XYZ,” Saintia Mat., vol. 1, no. 5, pp. 407-418, 2013.

[2] S. E. Bibri, J. Krogstie, and M. Kärrholm, "Compact city planning and development: Emerging practices and strategies for achieving the goals of sustainability," Dev. Built Environ., vol. 4, no. March, p. 100021, 2020, doi: 10.1016/j.dibe.2020.100021.

[3] W. Widayani, P. Purwanto, and D. Sutisnanto, "Survei Kepadatan Arus Lalu Lintas di Persimpangan Penceng Jalan RA. Rukmini, Kecapi Kebupaten Jepara,” Rev. Civ. Eng., vol. 1, no. 1, pp. 19-24, 2017.

[4] S. Meutia, S. M. Saleh, and Azmeri, “Analisis Kemacetan Lalu-Lintas Pada Kawasan Pendidikan (Studi Kaus Jalan Pocut Baren Kota Banda Aceh),” J. Tek. Sipil, vol. 1, no. 1, pp. 243-250, 2017.

[5] S. H. B. Harmadi, "How Does Congestion Matter for Jakarta'S Citizens?," J. Indones. Econ. Bus., vol. 29, no. 3, pp. 220-238, 2015, doi: 10.22146/jieb.10312.

[6] B. P. Statistik, "Jumlah Penduduk Indonesia Tahun 2020,” 2020. .

[7] A. de Rozari and Y. H. Wibowo, "Faktor-faktor Yang Menyebabkan Kemacetan Lalu Lintas di Jalan Utama Kota Surabaya,” J. Penelit. Adm. Publik, vol. 1, no. 1, pp. 42-57, 2015, doi: 10.1007/s13398-014-0173-7.2.

[8] E. Zadobrischi, L. M. Cosovanu, and M. Dimian, "Traffic flow density model and dynamic traffic congestion model simulation based on practice case with vehicle network and system traffic intelligent communication," Symmetry (Basel)., vol. 12, no. 7, 2020, doi: 10.3390/sym12071172.

[9] D. Saepuloh, M. Ramdhan, R. Bramawanto, and S. Suryo Sukoraharjo, "Metode Adaptive Neuro Fuzzy Inference System Pada Aplikasi Sistem Cerdas Pendugaan Produksi Garam,” J. Kelaut. Nas., vol. 14, no. 2, pp. 125-134, 2019, doi: 10.15578/jkn.v14i2.7910.

[10] S. Bhattacharyya, "Neural Networks: Evolution, Topologies, Learning Algorithms and Applications," Inf. Sci. Ref., pp. 450-498, 2011, doi: 10.4018/978-1-61350-429-1.

[11] B. Fatkhurrozi, M. A. Muslim, and D. R. Santoso, "Penggunaan Artificial Neuro Fuzzy Inference Sistem (ANFIS) dalam Penentuan Status Aktivitas Gunung Merapi,” J. EECCIS, vol. 6, no. 2, pp. 113-118, 2012.

[12] S. H. Ling, "A New Neural Network Structure: Node-to-Node-Link Neural Network," J. Intell. Learn. Syst. Appl., vol. 02, no. 01, pp. 1-11, 2010, doi: 10.4236/jilsa.2010.21001. 
[13] J. Zhou et al., "Graph neural networks: A review of methods and applications," AI Open, vol. 1, no. December 2020, pp. 57-81, 2020, doi: 10.1016/j.aiopen.2021.01.001.

[14] A. A. AlDahdouh, "Does artificial neural network support connectivism's assumptions?," Int. J. Instr. Technol. Distance Learn., vol. 14, no. 3, pp. 3-26, 2017, [Online]. Available:

http://itdl.org/Journal/Mar_17/Mar17.pdf\#page=7\%0Ahttps://papers.ssrn.com/sol3/pap ers.cfm?abstract_id=3063496.

[15] W. Wang, L. Wu, H. Ye, H. Wang, and R. Zhu, "Link Prediction Based on Deep Convolutional Neural Network," Information, vol. 10, no. 5, 2019, doi: 10.3390/info10050172.

[16] N. Nikentari, M. Bettiza, and H. Sasty Pratiwi, "Prediksi Kecepatan Angin Menggunakan Adaptive Neuro Fuzzy (ANFIS) dan Radial Basis Function Neural Network (RBFNN)," J. Edukasi dan Penelit. Inform., vol. 4, no. 1, pp. 70-75, 2018, doi: 10.26418/jp.v4i1.25558.

[17] Y. Wu, B. Zhang, J. Lu, and K.-L. Du, "Fuzzy Logic and Neuro-fuzzy Systems: A Systematic Introduction," Int. J. Artif. Intell. Expert Syst., vol. 2, no. 2, pp. 47-80, 2011.

[18] M. Junaidi and R. D. Rahayu, "Prediksi Financial Distress Menggunakan Model Neuro Fuzzy dan Rasio Altman,” J. Ilm. Manaj. Bisnis, vol. 6, no. 1, pp. 95-109, 2020.

[19] M. I. Azhar and W. F. Mahmudy, "Prediksi Curah Hujan Menggunakan Metode Adaptive Neuro Fuzzy Inference System (ANFIS)," J. Pengemb. Teknol. Inf. dan Ilmu Komput., vol. 2, no. 11, pp. 4932-4939, 2018.

[20] A. H. Saputra, Tarno, and B. Warsito, “Analisis Data Runtun Waktu dengan Metode Adaptive Neuro Fuzzy Inference System (ANFIS),” J. Gaussian, vol. 1, no. 1, pp. 3140, 2012.

[21] E. A. Ardiansyah, R. Mardiati, and A. Fadhil, "Aplikasi Peramalan Kebutuhan Beban Listrik Menggunakan Metode Adaptive Neuro Fuzzy Inference System (ANFIS),” TELKA - Telekomun. Elektron. Komputasi dan Kontrol, vol. 3, no. 1, pp. 36-48, 2017, doi: 10.15575/telka.v3n1.36-48. 